\title{
A Model of Green Consumption Behavior Constructed by the Theory of Planned Behavior
}

\author{
Shwu-Ing $\mathrm{Wu}^{1} \&$ Jia-Yi Chen ${ }^{1}$ \\ ${ }^{1}$ Department of Business Administration, National Chin-Yi University of Technology, Taiwan, R.O.C. \\ Correspondence: Professor Shwu-Ing Wu, Department of Business Administration, National Chin-Yi University \\ of Technology, No.57, Section 2, Chungshan Road, Taiping, Taichung, Taiwan 411, R.O.C. Tel: \\ 886-4-2392-4505. E-mail: wusi@ncut.edu.tw
}

Received: August 5, 2014 Accepted: August 28, 2014 Online Published: September 28, 2014

doi:10.5539/ijms.v6n5p119 URL: http://dx.doi.org/10.5539/ijms.v6n5p119

\begin{abstract}
In recent years, global warming has become a widespread well-publicized issue. As the general public have become aware of the importance of protecting the environment, consumers have started to evidence a marked preference for green products. This study constructed a model describing the relationships among perceived benefit of green consumption behavior, perceived risk, moral responsibility, normative belief, control strength, control belief, attitude, subjective norms, behavior control, behavior intention, and actual behavior.

An analysis of 560 valid questionnaires resulted in six main findings: (1) Perceived benefit of green consumption has a significantly positive impact on consumer attitude. (2) Perceived risk of green consumption has a significantly negative impact on consumer attitude. (3) Normative belief and moral responsibility both have significantly positive impacts on consumer subjective norms. (4) Control strength and control belief both have significantly positive impacts on consumer behavior control. (5) Attitude, subjective norms and behavior control both have significantly positive impacts on consumer behavior intention. (6) Behavioral intention and behavior control both have significantly positive impacts on actual consumer behavior. The results of this study provide reference to industry managers in the formulation of green marketing strategy.
\end{abstract}

Keywords: green consumption behavior, theory of planned behavior

\section{Introduction}

Pursuit of economic growth has led to severe damage to the environment. Kates (2000) pointed out that the over-exploitation of natural resources has had a significantly negative impact and is the result of the population explosion and the corresponding leap in consumption. McDougally (1993) argues that environmental destruction is principally caused by over-consumption, making green consumption the key to sustainable development (Goldblatt, 2005; Peattie, 1992). To reduce the destruction caused by consumerism, Kates (2000) proposed the 3R principle: reduce, reuse, and recycle. Ottman (1993) goes so far as to suggest that green consumption could be the trigger for a worldwide green revolution. Therefore the consumer has a critical role to play in environmental protection.

Green consumption is not a result of statutory control. Rather, it arises from the values held by the consumer. Chan (1999) found that green consumption behavior is significantly related to concern for the environment and behavioral intentions, and that green consciousness and the promotion of environmental protection and green consumption by the government are both effective predictors of green consumption behavior. Thus, education of the consumer can lead to changes in consumption behavior and the incorporation of green choices into his/her daily life. Entrepreneurial marketing can serve to fulfill this function and go a long way towards shaping environmentally sustainable economic development (Sarma, Septiani, Dewi \& Siregar, 2013).

According to the Theory of Planned Behavior (TPB) proposed by Ajzen (2002), behavioral intention is an important predictor of actual behavior. Behavioral intention is influenced by the following three factors: attitude, subjective norm, and behavioral control. Attitude is influenced by behavioral belief and outcome evaluation; subjective norm is influenced by normative belief and motivation; perceived behavioral control (PBC) is influenced by control belief and control strength. These factors work together to form a complete theoretical framework for predicting human behavior. 
This study applied the above framework to explore the green consciousness of consumers and the way it affects purchasing behavior. By using perceived benefit, perceived risk, normative belief, moral obligation, control strength, and control belief as independent variables, attitude, subjective norm, PBC, and behavioral control as mediators, and actual behavior as the dependent variable, this study aimed to develop a relationship model of green consumption behavior. Using relevant literature we developed a research framework and drafted a questionnaire survey. The target population for sampling was autonomous adult consumers in Taiwan.

\section{Literature Review}

\subsection{Theory of Planned Behavior}

In their Theory of Planned Behavior (TPB), Ajzen and Fishbein (1980) defined behavioral intention as one's willingness to perform a specific behavior, and proposed it to be the main predictor of actual behavior. Behavioral intention is influenced by attitude, subjective norm, and perceived behavior control (PBC). Further examination of the constructs of TPB showed that attitude is influenced by perceived benefit and perceived risk (Mehrens, Cragg \& Mills, 2001); subjective norm is influenced by normative belief and moral obligation; and PBC is influenced by control strength and control belief (Ajzen, 2002). All of these factors work together to determine behavioral intention and actual behavior.

\subsection{Perceived Benefit}

Lovelock and Wirtz (2007) contended that perceived benefit is the consumer's perception of the quality and functionality of a product and his/her anticipation of his/her expectations being met by consumption of the product. The overall benefit demanded by the consumer is not only satisfaction with the functioning of a product, but also additional beneficial effects (Drennan, Mort, and Previte, 2006). Chandon, Wansink, and Laurent (2000) separated perceived benefit into six constructs: monetary saving, quality, convenience, value, expression, and entertainment. Aaker (1996) pointed out three aspects of perceived benefit: functional benefits, emotional benefits, and self-expressive benefits. Babin, Darden and Griffin (1994) stated that consumers' purchasing experience results in utilitarian and hedonic benefits. For the purposes of this study, we defined perceived benefit as the consumer's perception of the quality and functionality of green consumption behavior and his/her anticipation of his/her expectations being met by consumption of the green product.

\subsection{Perceived Risk}

Stone and Gronhaug (1993) described perceived risk as the possible loss incurred by the consumer while in pursuit of the most satisfactory outcome. Peter and Ryan (1976) declared that perceived risk is the loss of subjective anticipation, namely, the consumer's perceived uncertainty about the possible outcome. Baird and Thomas (1985) confirmed this definition of perceived risk as uncertainty, further including the assessment of the controllability of that uncertainty. Roselius (1971) specified the perceived risk consumers run while purchasing: time loss, hazard loss, ego loss, and money loss. Jacoby and Kaplan (1974) measured perceived risk in terms of the following constructs: financial risk, performance risk, physical risk, psychological risk, and social risk. Hsu and Lin (2006) further specified that the uncertainty experienced by consumers includes functional risk, financial risk, psychological risk, physical risk, social risk, and time risk.

\subsection{Attitude}

Fishbein and Ajzen (1975) defined attitude as one's positive/negative evaluation of a specific behavior. Hoyer and Macinnis (2003) also considered attitude to be the positive or negative evaluation of an object, action, issue, or person. MacKenzie et al. (1986) argued that measurement of attitude should be conducted in two aspects: cognition and emotion. Evaluation constitutes the cognitive aspect, while fondness constitutes the emotional aspect. Sears, Peplau, and Taylor (1991) pointed out that the assessment of attitude should consist of three aspects: cognition, emotion, and behavior. Ajzen (2008) proposed that instrumental assessment (valuable or not) and empirical assessment (delightful or not) are the two assessment systems influencing the inclination of attitude.

\subsection{Normative Belief}

Wooten and Reed (2004) suggested two factors influence one's susceptibility to societal pressure: nature (part of one's inherent character) and nurture (the attitudes inherited from one's family and cultural background). Normative belief is one's perception of to what degree one should yield to social pressure (Ajzen \& Fishbein, 1980). Due to the lack of measurement instruments for normative belief in relevant literature, the present study developed its own measurement items drawing from the definition of normative belief given by Ajzen and Fishbein (1980). 


\subsection{Moral Obligation}

Kujala (2001) considered moral obligation to be the code of conduct regulating one's behavior. Frankena (1970) pointed out that moral obligation involves assessing whether one's behavior fits social norms, and can be influenced by moral identification and moral emotion. Moral obligation determines which behavior is righteous and which is necessary; that is, it is a judgment of value (Kohlberg, 1984). Moral obligation involves fairness and justice rather than legal considerations (Carroll, 1996). Trevino (1986) divided moral responsibility into two constructs: cognitive evaluation and moral judgment. Reidenbach and Robin (1990) developed a multidimensional ethics scale including concepts of justice, deontology, relativism, utilitarianism, and egoism.

\subsection{Subjective Norm}

Fishbein and Ajzen (1975) declared that subjective norm is the perceived social pressure that encourages one to engage in a specific behavior. Subjective norm is a prevalent behavioral standard followed by a social group (Coleman, 1990). That is, subjective norm is the measure of pressure exerted by the social group which the individual takes into account before making a behavioral decision (Venkatesh \& Davis, 2000). Fishbein and Ajzen (1975) proposed that social pressure and the social group are the constructs of subjective norm. Ajzen (1991) further pointed out that social pressure and compliance motivation are the functions of subjective norm. When predicting the behavior of an individual, the specific behavior will be related to the reference group. Schiffman and Kanuk (2000) measured subjective norm by the individual and the reference group.

\subsection{Control Strength}

Control strength refers to the degree to which one is influenced by resources, opportunities, or obstacles (Ajzen, 1989; 1991). Triandis (1989) proposed that control strength is comprised of factors facilitating or impeding the target behavior. Ajzen (1989) defined control strength as the resources (i.e., money, time, and energy) and the opportunities one needs to complete a behavior. Due to the lack of measurement instruments for control strength in the relevant literature, the present study developed its own measurement items based on the definition of control strength given by Ajzen (1989).

\subsection{Control Belief}

Ajzen (1989) stated that control belief is the individual's belief in the existence of factors that facilitate or impede performance of the behavior, and that these beliefs can be based on past experience. Rotter (1954) considered control belief to be the conviction that a certain behavior is achievable. Rotter (1966) further divided control belief into internal belief and external belief: the former involves factors controlled by the individual including capability and personal traits, while the latter involves external factors such as luck or opportunity. Due to the lack of measurement instruments for control belief in the relevant literature, the present study developed its own measurement items based on the definitions of Ajzen (1989) and Rotter (1966).

\subsection{Behavioral Control}

Averill (1973) defined behavioral control as the reaction of an individual to an event or factor that threatens the successful performance of his intended action. Bateson (2000) concurred with this description of behavioral control as actual rather than perceived. Fishbein and Ajzen (1975) argued that behavioral control is difficulty perceived by the individual while performing a specific behavior. Ajzen (1991), and Pavlou and Fygenson (2006) suggested that resource limitation and self-efficacy are two constructs capable of measuring behavioral control. Resource limitation refers to the availability of resources (Pedersen, 2005), while self-efficacy refers to one's belief in one's own competence (Bandura, 1997. Taylor and Todd (1995) proposed the following three constructs for the measurement of behavioral control: self-efficacy, resource facilitating conditions, and technology facilitating conditions.

\subsection{Intention}

Intention is a measure of the extent to which one is likely to perform a specific behavior, or, in other words, one's willingness to perform a specific behavior (Ajzen, 1991; Fishbein and Ajzen, 1975). Hankins, French, and Horne (2000) defined behavioral intention as the intensity that consumer shows on a spontaneously participating behavior. Blackwell et al. (2001) proposed five constructs for the measure of intention: purchase intention, repurchase intention, research intention, expenditure intention, and consumption intention. Boulding et al. (1993) suggested that the behavioral intention of consumers can be measured by repurchase intention and the willingness to recommend the product to others.

\subsection{Actual Behavior}

Consumer behavior is a set of activities humans perform in order to satisfy their desires. These activities include 
searching, choosing, purchasing, using, evaluating, and disposing, which fall into the domains of the subjective mental field and the objective material field (Kotler, 2000). Bearden, Ingram, and LaForge (2001) further explained that consumer behavior is an evolving process involving interaction between mental, emotion, and material fields. Kotler and Armstrong (2004) proposed the following questions for use in the measurement of actual behavior: What does one buy? Where does one buy? How does one buy? How much does one buy? When does one buy? Why does one buy? Elena and Eva (2007) discussed green consumption, pointing out that it is performed via consumers' choices to reduce environmental damage, such as declining to purchase polluting products, and support of reusable products.

\section{Research Hypotheses}

\subsection{Relationships among Perceived Benefit, Perceived Risk and Attitude}

Prior research has shown that perceived benefit is positively related to attitude, while perceived risk exerts a negative effect on attitude. For example, in the research conducted by Mehrens, Cragg and Mills (2001) on e-trading, it was found that lower cost, increased speed and informational transparency enhanced consumer attitudes. Furthermore, Rohm and Swaminathan (2004) demonstrated that online shopping grants consumers time and energy savings, leading to positive attitudes towards this activity. Tan (2002) and Chiou et al. (2005) found that the legal risks of piracy negatively influence consumer attitudes towards products with suspect copyright. The study of Teo and Pok (2003) on online shopping via Wireless Application Protocol (WAP) phone further confirmed these results. Synthesis of the findings of these studies gives rise to the following hypotheses:

H1a: The perceived benefit of green consumption is positively related to consumer attitude.

H1b: The perceived risk of green consumption is negatively related to consumer attitude.

\subsection{Relationships among Normative Belief, Moral Obligation, and Subjective Norm}

Newhouse (1990) noted that a strong belief in social norms usually guarantees behavior in line with social expectations; thus, normative belief is an important factor influencing an individual's behavior (Festinger, 1954). The TPB defines subjective norm as the social pressure taken into considered before performance of a specific behavior. Such pressure is usually exerted by a social group with strong social ties (Ajzen \& Fishbein, 1975).

Shaw et al. (2000) pointed out that moral obligation reflects the inner moral code of the individual, representing his/her personal standard of right and wrong. Schwartz and Tessler (1972) contended that attitude and subjective norm influence behavioral intention, while personal subjective norm is influenced by moral obligation. The research of Beck and Ajzen (1991) on ethical behavior showed that when determining whether to perform a specific behavior, the factors exerting influence are not only personal moral obligation, but also social pressure. Thus, the present study posits the following relationships:

H2a: The normative belief of the consumer regarding green consumption is positively related to the subjective norm.

$\mathrm{H} 2 \mathrm{~b}$ : The moral obligation felt by the consumer regarding green consumption is positively related to the subjective norm.

\subsection{Relationships among Control Strength, Control Belief, and Behavioral Control}

Ajzen (1991) declared that PBC comprises control strength and control belief. Control strength is the confidence one possesses in one's ability to complete a specific behavior; while control belief is one's self-assessment of one's ability to complete a specific behavior. In the context of social cognition theory, Bandura (1986) suggested that control ability is one's capability to control specific performance, and self-efficacy is one's belief in one's ability to successfully perform the behavior. These two notions are similar to Ajzen's (1991) concepts of control strength and control belief. Hill et al. (1987) suggested that self-efficacy can be widely applied for the prediction and explanation of behavior. Thus, PBC is influenced by control belief and control strength (Ajzen, 2002). Therefore, the present study formulated the following hypotheses:

H3a: The control strength of the consumer regarding green consumption is positively related to behavioral control.

H3b: The control belief of the consumer regarding green consumption is positively related to behavioral control.

\subsection{Relationships among Attitude, Subjective Norm, PBC, and Behavioral Intention}

Ajzen (1991) proposed the TPB as an extension of the Theory of Reasoned Action (Fishbein \& Ajzen, 1975) to predict and explain human behavior in terms of a limited set of constructs: attitude, subjective norm, and PBC. The theoretical framework of TPB has been tested by multiple studies. For example, Westaby (2005) designed 
four experiments to test the hypotheses of TPB. Ajzen and Driver (1991), Cheng, Lam, and Hsu (2005), Baker, Al-Gahtani, and Hubona (2007), and Cronan and Al-Rafee (2008) all confirmed the findings suggested by the TPB model. Thus, the present study posits the following relationships in the context of green consumption behavior:

H4a: The attitude of the consumer towards green consumption is positively related to behavioral intention.

$\mathrm{H} 4 \mathrm{~b}$ : The subjective norm of the consumer regarding green consumption is positively related to behavioral intention.

$\mathrm{H} 4 \mathrm{c}$ : The $\mathrm{PBC}$ of the consumer regarding green consumption is positively related to behavioral intention.

\subsection{Relationship between Behavioral Intention and Actual Behavior}

Fishbein and Ajzen (1975) pointed out the strong relationship between behavioral intention and actual behavior, and applied the TPB to test this relationship. In the study of Westaby (2005) applying the Theory of Reasoned Action, it was found that when the consumer shows inclination toward a specific product, the likelihood of the product being purchased is much greater. That is, purchasing behavior is positively related to purchasing intention. In addition, Mostafa (2007) has proven that behavioral intention regarding green consumption is positively related to actual behavior. Thus, the present study posits the following hypothesis:

H5: The behavioral intention of the consumer regarding green consumption is positively related to actual behavior.

\subsection{Relationship between Behavioral Control and Actual Behavior}

Ajzen (2002) considered behavioral control to be the resources and opportunities available to the consumer, and it therefore includes the potential obstacles to successful completion of the activity. In short, actual behavior is influenced by behavioral control. Norman and Conner (2005), in their study predicting health behavior, confirmed that behavioral control significantly affects behavioral intention and actual behavior. The study of Ajzen and Madden (1986) showed that when the predicted behavior is non-volitional, or is subject to a set of measurable controls, then PBC exerts a direct influence on actual behavior. On this basis, we hypothesized the following relationship:

H6: Behavioral control related to green consumption is positively related to actual behavior.

\section{Research Design}

\subsection{Framework}

Applying the framework of TPB proposed by Ajzen (1991; 2002), this study used perceived benefit, perceived risk, normative belief, moral obligation, control strength, and control belief as independent variables, investigating their influence on the mediating variables (i.e., attitude, subjective norm, behavioral control, and behavioral intention) and the dependent variable (i.e., actual behavior). The selected framework is depicted in Figure 1.

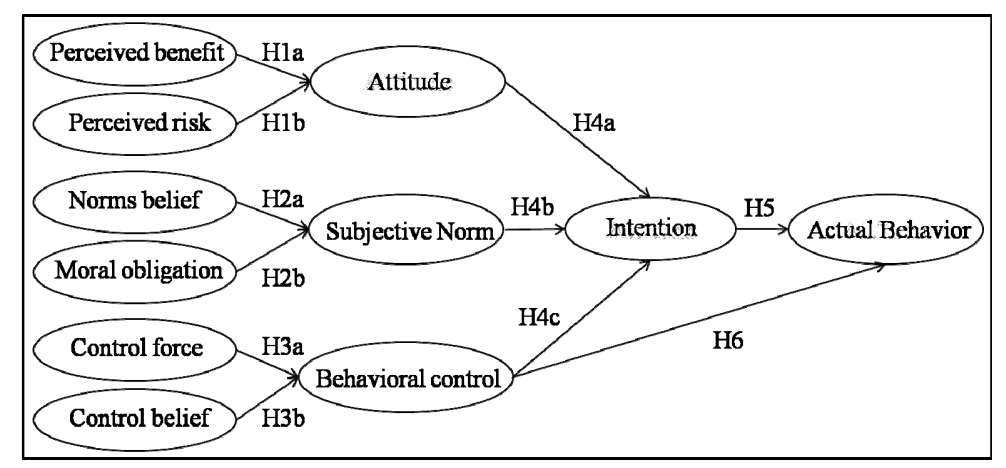

Figure 1. Research model

\subsection{Variables in Discussion}

The questionnaire was based on relevant literature and modified for the particular context of the present study. The questionnaire was divided into two parts: the first solicited information related to green consumption 
behavior, with responses measured on a seven-point Likert-type scale; the second captured demographic information with a nominal scale. The results from the second part of the questionnaire are presented in Table 1.

Table 1. Variables and operational definitions

\begin{tabular}{|c|c|c|c|c|}
\hline Constructs & & Operational definitions & Literature & Scale \\
\hline Perceived benefit & 6 & Consumer's perceived value on green consumption. & $\begin{array}{l}\text { Chandon, Wansink, and } \\
\text { Laurent(2000) }\end{array}$ & \multirow{11}{*}{$\begin{array}{l}\text { Seven-point } \\
\text { Likert Scales }\end{array}$} \\
\hline Perceived risk & 6 & $\begin{array}{l}\text { The uncertainty faced by the consumer when } \\
\text { practicing green consumption. }\end{array}$ & Kaplan(1974) & \\
\hline Attitude & 4 & $\begin{array}{l}\text { Consumer's impression, feeling, and evaluation to the } \\
\text { green consumption. }\end{array}$ & Ajzen: 2008) & \\
\hline Norms belief & 4 & $\begin{array}{l}\text { Consumer's perception on the important reference } \\
\text { group and the pressure along with on green } \\
\text { consumption }\end{array}$ & $\begin{array}{l}\text { Ajzen and Fishbein } \\
(1980)\end{array}$ & \\
\hline Moral obligation & 3 & $\begin{array}{l}\text { The value judgment of the consumer to the green } \\
\text { consumption. }\end{array}$ & Trevino(1986) & \\
\hline Subjective norm & 4 & $\begin{array}{l}\text { The consumer's green consumption is affected by } \\
\text { reference group. }\end{array}$ & $\begin{array}{l}\text { Fishbein and Ajzen } \\
(1975 ; 1980)\end{array}$ & \\
\hline Control force & 5 & $\begin{array}{l}\text { The opportunity and resource available for the green } \\
\text { consumption practice. }\end{array}$ & Ajzen(1989) & \\
\hline Control belief & 3 & $\begin{array}{l}\text { The opinion and special treatment of the consumer on } \\
\text { green consumption. }\end{array}$ & $\begin{array}{l}\text { Rotter(1966) and Ajzen } \\
\text { (1989) }\end{array}$ & \\
\hline Behavior control & 5 & $\begin{array}{l}\text { Resources sufficient to ensure the success of } \\
\text { performing of the green consumption owned by the } \\
\text { consumer, }\end{array}$ & $\operatorname{Ajzen}(1991)$ & \\
\hline Intention & 4 & $\begin{array}{l}\text { The possibility for consumer to perform green } \\
\text { consumption behavior. }\end{array}$ & Boulding et al.(1993) & \\
\hline Actual behavior & 5 & Consumer practice green consumption. & Elena and Eva (2007) & \\
\hline Personal information & 8 & Personal background and information of the consumer. & $\begin{array}{l}\text { Gender, Age, Residence, } \\
\text { Level of education, } \\
\text { Occupation, Personal } \\
\text { average income, } \\
\text { motivation of purchasing } \\
\text { environmental friendly } \\
\text { products. }\end{array}$ & Nominal scale \\
\hline
\end{tabular}

\subsection{Sampling}

Our target population was autonomous adult consumers in Taiwan. Participants were recruited using convenience sampling over a three-month period, from July 1, 2011 to September 30, 2011.

\subsection{Questionnaire Pretest and Pilot Study}

Prior to data collection, the measurement instrument was pretested through a pilot study. Using convenience sampling, 30 autonomous consumers were interviewed. These interviews revealed some ambiguities in the questionnaire draft. Following modification, another 100 respondents were selected through convenience sampling. Their responses were used to perform validity and reliability analysis.

The values of Cronbach's alpha for the constructs ranged from 0.833 to 0.922 . Since all of the values exceeded the standard of 0.7 (Nunnally, 1978), the reliability of the model was deemed adequate. In the results of factor analysis, all of the eigenvalue values of the constructs exceeded 1, cumulative e variation exceeded 0.5 , factor loadings all were close to or exceeded 0.6 , and the item-to-total correlation coefficients all were close to or exceeded 0.5. Thus, all constructs possessed convergent validity (Kerlinger, 1978; Kaiser, 1958) and the revised questionnaire was considered appropriate for the formal survey.

\section{Data Analysis and Research Results}

\subsection{Sample Characteristics}

Out of 600 questionnaires that were distributed through convenience sampling, 560 valid questionnaires were returned. Slightly more than half of the sample was male (50.5\%). The largest age group was 21-30 years old (30.4\%), and the second largest group was 31-40 years old (27.5\%). 56.8\% of the respondents were residents in 
northern Taiwan. In terms of education, the largest group were college graduates $(66.3 \%)$, and the second largest group held master's degrees (13.2\%). The largest group in terms of occupation were students $(28.8 \%)$, and the second largest group were workers in the service industry (27.0\%). For personal average income, the largest group earned below 10,000 NT dollars monthly (34.1\%), and the second largest group earned from 10,001 to 30,000 dollars $(28.39 \%)$. In terms of job title, the largest group were ordinary employees $(44.5 \%)$, the second largest group were students $(28.8 \%)$. $76.1 \%$ of the respondents reported environmental protection as their motivation for purchasing environmentally friendly products.

\subsection{Reliability and Validity Assessment}

After finishing the formal survey, reliability and validity assessments were conducted on all constructs; results of the analysis are presented in Table II. For all constructs, Nunnally's (1978) suggested minimum threshold of 0.7 for Cronbach's alpha was exceeded, as was Kerlinger's (1978) minimum threshold of 0.5 for the item-to-total correlation coefficient. Thus, the reliability of the questionnaire was deemed adequate. For factor analysis, Kaiser (1958) recommends that the values of the extracted factors should be over 1, the factor loadings of the variables should exceed 0.5 , and the value of cumulative explained variation should be over 0.5 . All values exceeded or were close to these standards, confirming the convergent validity of the questionnaire. Gaski and Nevin (1985) stated that the correlation coefficient between any two constructs should be no more than the value of Cronbach's alpha of any single construct in order to ensure discriminant validity; this condition was also met.

Table 2. Reliability and validity assessment of the formal survey

\begin{tabular}{|c|c|c|c|c|c|}
\hline Description of variables & Item to total & $\begin{array}{l}\text { Factor } \\
\text { loading }\end{array}$ & Eigenvalue & $\begin{array}{l}\text { Cumulative } \\
\text { explained } \\
\text { variation } \%\end{array}$ & Cronbach's alpha \\
\hline \multicolumn{6}{|l|}{ Perceived benefit(PB) } \\
\hline $\begin{array}{l}\text { I think environmental friendly products are more } \\
\text { trustworthy. }\end{array}$ & 0.655 & 0.773 & \multirow{6}{*}{3.727} & \multirow{6}{*}{62.125} & \multirow{6}{*}{0.877} \\
\hline $\begin{array}{l}\text { I think environmental friendly products are with better } \\
\text { quality. }\end{array}$ & 0.739 & 0.837 & & & \\
\hline I think practicing green consumption is delightful. & 0.576 & 0.699 & & & \\
\hline $\begin{array}{l}\text { I think purchasing environmental friendly products is } \\
\text { more economical. }\end{array}$ & 0.666 & 0.772 & & & \\
\hline I think environmental products are much more durable. & 0.713 & 0.808 & & & \\
\hline $\begin{array}{l}\text { Environmental friendly products can reach a better } \\
\text { effect. }\end{array}$ & 0.745 & 0.798 & & & \\
\hline \multicolumn{6}{|l|}{ Perceived risk(PR) } \\
\hline $\begin{array}{l}\text { I think purchasing environmental friendly products may } \\
\text { gain less than the lost. }\end{array}$ & 0.523 & 0.643 & \multirow{6}{*}{3.743} & \multirow{6}{*}{62.387} & \multirow{6}{*}{0.877} \\
\hline $\begin{array}{l}\text { I think practicing green consumption cannot be } \\
\text { approved by the community. }\end{array}$ & 0.641 & 0.751 & & & \\
\hline $\begin{array}{l}\text { I think practicing green consumption cannot enhance my } \\
\text { personal image. }\end{array}$ & 0.701 & 0.802 & & & \\
\hline $\begin{array}{l}\text { I think using environmental friendly products cannot } \\
\text { guaranty the safety }\end{array}$ & 0.756 & 0.849 & & & \\
\hline $\begin{array}{l}\text { I think using the environmental friendly product cannot } \\
\text { improve my health. }\end{array}$ & 0.731 & 0.832 & & & \\
\hline $\begin{array}{l}\text { I think the function of the environmental products is } \\
\text { poorer than expectation. }\end{array}$ & 0.751 & 0.842 & & & \\
\hline \multicolumn{6}{|l|}{ Attitude(A) } \\
\hline I think practicing green consumption is righteous. & 0.819 & 0.898 & \multirow{4}{*}{3.349} & \multirow{4}{*}{83.735} & \multirow{4}{*}{0.935} \\
\hline I think practicing green consumption is valuable. & 0.875 & 0.933 & & & \\
\hline I think practicing green consumption is delightful. & 0.839 & 0.910 & & & \\
\hline I think it's wise to practice green consumption. & 0.854 & 0.919 & & & \\
\hline \multicolumn{6}{|l|}{ Norms belief (NB) } \\
\hline My families think I should practice green consumption. & 0.886 & 0.936 & \multirow{4}{*}{3.540} & \multirow{4}{*}{88.503} & \multirow{4}{*}{0.957} \\
\hline My friends think I should practice green consumption & 0.885 & 0.935 & & & \\
\hline $\begin{array}{l}\text { I value the opinion and feeling of my family on my } \\
\text { green consumption. }\end{array}$ & 0.906 & 0.948 & & & \\
\hline $\begin{array}{l}\text { I value the opinion and feeling of my friends on my } \\
\text { green consumption. }\end{array}$ & 0.898 & 0.943 & & & \\
\hline
\end{tabular}




\begin{tabular}{|c|c|c|c|c|c|}
\hline \multicolumn{6}{|l|}{ Moral obligation(MO) } \\
\hline $\begin{array}{l}\text { I think purchasing environmental friendly products is } \\
\text { fulfilling my responsibility to the environment. }\end{array}$ & 0.822 & 0.925 & \multirow{3}{*}{2.513} & \multirow{3}{*}{83.780} & \multirow{3}{*}{0.903} \\
\hline $\begin{array}{l}\text { I think purchasing environmental friendly products is } \\
\text { helpful for environmental protection. }\end{array}$ & 0.847 & 0.937 & & & \\
\hline $\begin{array}{l}\text { I think purchasing environmental products meets the } \\
\text { demand of the moral code. }\end{array}$ & 0.749 & 0.883 & & & \\
\hline \multicolumn{6}{|l|}{ Subjective norm $(\mathrm{SN})$} \\
\hline $\begin{array}{l}\text { I think purchasing environmental friendly products is } \\
\text { appropriate. }\end{array}$ & 0.813 & 0.906 & \multirow{4}{*}{3.107} & \multirow{4}{*}{77.675} & \multirow{4}{*}{0.904} \\
\hline $\begin{array}{l}\text { I think purchasing environmental friendly products is } \\
\text { righteous. }\end{array}$ & 0.820 & 0.910 & & & \\
\hline $\begin{array}{l}\text { I think purchasing environmental friendly products is } \\
\text { necessary. }\end{array}$ & 0.744 & 0.852 & & & \\
\hline $\begin{array}{l}\text { I think purchasing environmental friendly products is to } \\
\text { benefit other people as well as oneself. }\end{array}$ & 0.755 & 0.857 & & & \\
\hline \multicolumn{6}{|l|}{ Control force(CF) } \\
\hline $\begin{array}{l}\text { I have sufficient money to purchase environmental } \\
\text { friendly products. }\end{array}$ & 0.656 & 0.798 & \multirow{5}{*}{2.907} & \multirow{5}{*}{58.143} & \multirow{5}{*}{$0.81 \mathrm{C}$} \\
\hline $\begin{array}{l}\text { I have sufficient time to purchase environmental friendly } \\
\text { products. }\end{array}$ & 0.611 & 0.757 & & & \\
\hline I have sufficient resource to support green consumption. & 0.667 & 0.807 & & & \\
\hline $\begin{array}{l}\text { I have sufficient information and knowledge on } \\
\text { environmental friendly products. }\end{array}$ & 0.552 & 0.716 & & & \\
\hline I consider I am capable of practicing green consumption. & 0.574 & 0.729 & & & \\
\hline \multicolumn{6}{|l|}{ Control belief(CB) } \\
\hline It's easy for me to practice green consumption. & 0.630 & 0.822 & \multirow{3}{*}{2.278} & \multirow{3}{*}{75.930} & \multirow{3}{*}{0.841} \\
\hline $\begin{array}{l}\text { I can tell the differences between environmental } \\
\text { products and ordinary products. }\end{array}$ & 0.751 & 0.899 & & & \\
\hline I have much knowledge of green consumption. & 0.737 & 0.891 & & & \\
\hline \multicolumn{6}{|l|}{ Behavioral control(BC) } \\
\hline $\begin{array}{l}\text { I can make the decision to purchase environmental } \\
\text { friendly products. }\end{array}$ & 0.758 & 0.859 & \multirow{5}{*}{3.310} & \multirow{5}{*}{66.193} & \multirow{5}{*}{0.870} \\
\hline $\begin{array}{l}\text { I can participate in the decision-making process of } \\
\text { purchasing environmental friendly products. }\end{array}$ & 0.737 & 0.844 & & & \\
\hline $\begin{array}{l}\text { I can decide whether to purchase environmental friendly } \\
\text { products or not by myself. }\end{array}$ & 0.762 & 0.864 & & & \\
\hline $\begin{array}{l}\text { I am independent of purchasing environmental friendly } \\
\text { products. }\end{array}$ & 0.681 & 0.805 & & & \\
\hline $\begin{array}{l}\text { I am free to choose environmental friendly products } \\
\text { when purchasing. }\end{array}$ & 0.541 & 0.681 & & & \\
\hline \multicolumn{6}{|l|}{ Behavioral intention(BI) } \\
\hline $\begin{array}{l}\text { I would like to purchase environmental friendly } \\
\text { products. }\end{array}$ & 0.784 & 0.884 & \multirow{4}{*}{3.158} & \multirow{4}{*}{78.941} & \multirow{4}{*}{0.910} \\
\hline $\begin{array}{l}\text { I would like to consider purchasing environmental } \\
\text { friendly products first. }\end{array}$ & 0.831 & 0.912 & & & \\
\hline I would like to practice green consumption. & 0.864 & 0.931 & & & \\
\hline $\begin{array}{l}\text { I would like to recommend others to purchase } \\
\text { environmental friendly products. }\end{array}$ & 0.705 & 0.824 & & & \\
\hline \multicolumn{6}{|l|}{ Actual behavior(AB) } \\
\hline I prefer purchasing EPA-certified products. & 0.839 & 0.898 & \multirow{5}{*}{4.106} & \multirow{5}{*}{82.129} & \multirow{5}{*}{0.945} \\
\hline I prefer choosing product causing lesser pollution. & 0.892 & 0.934 & & & \\
\hline I prefer choosing energy saving products. & 0.843 & 0.902 & & & \\
\hline I prefer choosing environmental friendly products. & 0.885 & 0.930 & & & \\
\hline I prefer choosing products & 0.796 & 0.866 & & & \\
\hline
\end{tabular}

\subsection{Confirmatory Factor Analysis}

The present study used AMOS statistical software to conduct confirmatory factor analysis to test the efficiency of the 11 constructs. The ratio of goodness of fit to degrees of freedom should be no more than 3 (Carmines and MacIver, 1981), and the values of RMR and RMSEA should be less than 0.05, with the GFI, AGFI, NFI, CFI 
exceeding 0.9 (Bagozzi and Yi, 1988; Joreskog and Sorbom, 1989). Analysis returned the following values: chi-square $(\chi 2 / \mathrm{df})$ value of 1.619 , GFI value of 0.900 , AGFI value of 0.873 , NFI value of 0.940 , RFI value of 0.927 , CFI value of 0.976 , RMSEA value of 0.033 , and RMR value of 0.120 . Although the fit was not ideal, it was still within an acceptable level. Indeed, alternative thresholds have been suggested by Brown and Cudeck (1993) (GFI, AGFI, NFI less than 0.8 and RMSEA less than 0.05), Hair et al. (2006) (CFI over 0.9), and Chau and $\mathrm{Hu}(2001)\left(\chi^{2} / \mathrm{df}\right.$ no more than 3$)$. Therefore construct validity and measurement efficiency were assured.

\subsection{Structural Model Analysis}

The present study conducted a linear analysis of the structural relation model using AMOS statistical software to understand causality and correlation among the variables. The results show that the value of $\chi 2 / \mathrm{df}$ is 1.297 , the value of RMR is 0.224 , the value of GFI is 0.900 , the value of AGFI is 0.871 , the value of NFI is 0.941 , the value of RFI is 0.928 , the value of CFI is 0.977 , and the value of RMSEA is 0.033 . The fit of the model is therefore acceptable. In addition, the analysis showed that all the hypotheses were supported. The complete results are presented in Figure 2.

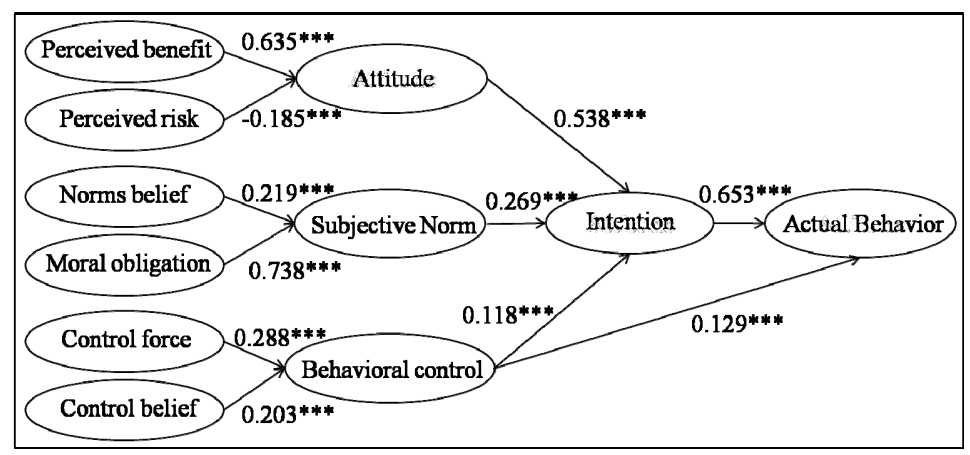

Figure 2. Result of SEM analyze $(* * *: p<0.001)$

\subsection{Hypothesis Testing and Inductive Analysis}

The empirical results show that (1) perceived benefit is significantly positively related to attitude; (2) perceived risk is significantly negatively related to attitude; (3) normative belief and moral obligation are significantly positively related to subjective norm; (4) control strength and control belief are significantly positively related to behavioral control; (5) the attitude, subjective norm, and behavioral control of the consumer are significantly positively related to behavioral intention; (6) behavioral intention and behavioral control are significantly positively related to actual behavior. Overall, it was found that actual green consumption behavior was most influenced by perceived benefit; that is, perceived benefit was the most effective factor triggering green consumption behavior. Table 3 shows the effects of each variable.

Table 3. Effect of influence of the variables

\begin{tabular}{lllll}
\hline Independent variable & Mediating variable & Dependent variable & Effect of indirect influence & Total effect \\
\hline Perceived benefit & Attitude* Intention & Actual behavior & $0.635^{*} 0.538 * 0.653=0.2231$ & 0.2231 \\
\hline Perceived risk & Attitude* Intention & Actual behavior & $-0.185 * 0.538 * 0.653=-0.0649$ & -0.0649 \\
\hline Norms belief & Subjective norm* Intention & Actual behavior & $0.219 * 0.269 * 0.653=0.0385$ & 0.0385 \\
\hline Moral obligation & Subjective norm* Intention & Actual behavior & $0.738^{*} 0.269 * 0.653=0.1296$ & 0.1296 \\
\hline Control force & Behavior control & Actual behavior & $0.288 * 0.129=0.0372$ & \multirow{2}{*}{0.0594} \\
\hline Control force & Behavior control*Intention & Actual behavior & $0.288 * 0.118 * 0.653=0.0222$ & \multirow{2}{*}{0.0418} \\
\hline Control belief & Behavior control & Actual behavior & $0.203 * 0.129=0.0262$ & $0.203 * 0.118 * 0.653=0.0156$ \\
\hline Control belief & Behavior control*Intention & Actual behavior & &
\end{tabular}

\section{Conclusions and Suggestions}

\subsection{Conclusions and Discussion}

This study set out to create a descriptive model incorporating the following variables: perceived benefit, perceived risk, normative belief, moral obligation, control strength, control belief, attitude, subjective norms, 
behavioral control, behavioral intention, and actual behavior. The results were as follows:

Perceived benefit is significantly positively related to attitude, while perceived risk is significantly negatively related to attitude. This is in line with the findings of Rohm and Swaminathan (2004), and Chiou et al. (2005). Therefore uncertainty affects consumers' evaluation of green consumption. However, the influence of perceived benefit is much higher than that of perceived risk.

Normative belief and moral obligation are significantly positively related to subjective norm. This supports the findings of Newhouse (1990), and Shaw et al. (2000).

Control strength and control belief are significantly positively related to behavioral control. This supports the claims of Ajzen's $(1991 ; 2002)$ that green consumption behavior is influenced by the availability of time and money, and that consumers are more likely to practice green consumption when they are confident of their capabilities.

Attitude, subjective norm, and behavioral control are significantly positively related to behavioral intention. This supports the findings of Cheng, Lam, and Hsu (2006), Baker, Al-Gahtani, and Hubona (2007), and Cronan and Al-Rafee (2008).

Behavioral intention and behavioral control are significantly positively related to actual behavior. This confirms the findings of Mostafa (2007), and Norman and Conner (2005).

Path analysis showed that the most influential variable is perceived benefit which, through the mediators of attitude and behavioral intention, determines actual behavior. The value of this path was 0.2231 .

\subsection{Managerial Implications}

This study investigated autonomous consumers in Taiwan to determine how green consciousness affects consumption behavior. The contributions of this study include a structural model and an efficient measurement instrument, both of which serve as important research tools. Further, our empirical results offer reference for industrial applications.

The results indicate that consumers with a higher level of green consciousness are more willing to practice green consumption. Therefore, higher levels of green consciousness lead to greater influence by the mediating factors of attitude, subjective norm, and behavioral control on behavioral intention and thereby actual behavior. Thus, this study recommends that corporations specifically market the green aspects of their products and simultaneously work to increase environmental awareness.

\subsection{Limitations and Directions for Future Research}

This study is subject to limitations. First, it could be argued that the high proportion of participants falling into the 21-40 year old group and resident in northern and central Taiwan means our sample was over-centralized. In future studies this could be modified by the employment of an alternative sampling technique. Second, green consciousness is a diverse and subtly nuanced concept. Consumers may have their own particular focus within this kind of awareness which could influence perceived benefits and risks of green consumption behavior, which would in turn result in differing levels of behavioral intention. Future studies could attempt to classify consumers in terms of their opinions regarding environmental protection in order to reveal differences in consumption behavior under the proposed model.

\section{References}

Aaker, D. A. (1996). Building Strong Brands. New York, NY: The Free Press.

Ajzen, I. (1989). Attitude structure and behavior. In S. J. Breckler \& A. G. Greenwald (Eds.), Attitude Structure and Function (pp. 241-274).

Ajzen, I. (1991). The theory of planning behavior. Organizational Behavior and the Human Decision Process, 50, 179-211. http://dx.doi.org/10.1016/0749-5978(91)90020-T

Ajzen, I. (2002). Perceived behavioral control, self-efficacy, locus of control, and the theory of planned behavior. $\begin{array}{lllll}\text { Journal of Applied Social } & \text { Psychology, } & \text { 32(4), }\end{array}$ http://dx.doi.org/10.1111/j.1559-1816.2002.tb00236.x

Ajzen, I. (2008). Consumer attitudes and behavior. In C. P. Haugtvedt, P. M. Herr, \& F. R. Cardes (Eds.), Handbook of Consumer Psychology (pp. 525-548). Lawrence Erlbaum Associates, NY.

Ajzen, I., \& Driver, B. L. (1991). Prediction of leisure participation from behavior, normative and control beliefs: An application of the theory of planned behavior. Leisure Sciences, 13, 185-204. 
http://dx.doi.org/10.1080/01490409109513137

Ajzen, I., \& Fishbein, M. (1980). Understanding Attitudes and Predicting Social Behavior. Prentice-Hall Press.

Ajzen, I., \& Madden, T. J. (1986). Prediction of goal directed behavior: Attitudes, intentions and perceived behavioral control. Journal of Experimental Social Psychology, 22, 453-474. http://dx.doi.org/10.1016/0022-1031(86)90045-4

Averill, J. R. (1973). Personal control over aversive stimuli and its relationship to stress. Psychological Bulletin, 80(4), 286-303. http://dx.doi.org/10.1037/h0034845

Babin, B. J., Darden, W. R., \& Griffin, M. (1994). Work and/or fun: measuring hedonic and utilitarian shopping value. Journal of Consumer Research, 20(4), 644-656. http://dx.doi.org/10.1086/209376

Bagozzi, R. P., \& Yi, Y. (1988). On the evaluation of structure equations models. Academic of Marketing Science, 16(1), 74-94. http://dx.doi.org/10.1007/BF02723327

Baird, I. S., \& Thomas, H. (1985). Toward a contingency model of strategic risk taking. The Academy of Management Review, 10(2), 230-243.

Baker, E. W., Al-Gahtani, S. S., \& Hubona, G. S. (2007). The effects of gender and age on new technology implementation in a developing country: Testing the theory of planned behavior. Information Technology \& People, 20(4), 352-375. http://dx.doi.org/10.1108/09593840710839798

Bandura, A. (1986). Social Foundations of Thought and Action. Englewood Cliffs, NJ: Prentice Hall.

Bandura, A. (1997). Self-Efficacy: The Exercise of Control. NY: Freeman.

Bateson, J. E. G. (2000). Perceived control and the service experience. In T. A. Swartz \& D. Iacobucci (Eds.), Handbook of Services Marketing and Management (pp. 127-144). California: Sage Publications. http://dx.doi.org/10.4135/9781452231327.n11

Bearden, W. O., Ingram, T. N., \& LaForge, R. W. (2001). Marketing: Principles \& Perspectives. McGraw-Hill, NY.

Beck, L., \& Ajzen, I. (1991). Predicting dishonest actions using the theory of planned behavior. Journal of Research in Personality, 25, 285-301. http://dx.doi.org/10.1016/0092-6566(91)90021-H

Blackwell, R. D., Miniard, P. W., \& Engle, J. F. (2001). Consumer Behavior (9th ed.). Australia: South-Western/Thomson Learning.

Boulding, W., Kalra, A., Staelin, R., \& Zeithaml, V. A. (1993). A dynamic process model of service quality: from expectations to behavioral intentions. Journal of Marketing Research, 30(2), 7-27. http://dx.doi.org/10.2307/3172510

Brown, M. W., \& Cudeck, R. (1993). Alternatives ways of assessing model fit. In K. A. Bollen \& J. S. Long (Eds.), Testing Structural Equation Model (pp. 136-162). Newbury Park, CA: Sage.

Carmines, E. G., \& Maclver, J. P. (1981). Analyzing models with unobserved variables. In G. W. Bohrnstedt \& E. F. Borgatta (Eds.), Social Measurement (pp. 65-115). CA: Sage Publications.

Carroll, A. B. (1996). Business and society. Ethics and Stakeholder Management, 3, 35-37.

Chan, R. Y. K. (1999). Environmental attitudes and behavior of consumers. Journal of International Consumer Marketing, 11(4), 25-52. http://dx.doi.org/10.1300/J046v11n04_03

Chandon, P., Wansink, B., \& Laurent, G. (2000). A benefit congruency framework of sales promotion effectiveness. Journal of Marketing, 64(4), 65-81. http://dx.doi.org/10.1509/jmkg.64.4.65.18071

Chau, P. Y. K., \& Hu, P. J. H. (2001). Information technology acceptance by individual professional: A model $\begin{array}{lllll}\text { comparison approach. } & \text { Decision } & \text { Sciences, } & 32(4), & \text { 699-719. }\end{array}$ http://dx.doi.org/10.1111/j.1540-5915.2001.tb00978.x

Cheng, S., Lam, T. \& Hsu, C. H. C. (2005). Testing the sufficiency of the theory of planned behavior: A case of customer dissatisfaction responses in restaurants. International Journal of Hospitality Management, 24(4), 475-492. http://dx.doi.org/10.1016/j.ijhm.2004.10.006

Chiou, J. S., Huang, C. Y., \& Lee, H. H. (2005). The antecedents of music piracy attitudes and intentions. Journal of Business Ethics, 57(2), 161-174. http://dx.doi.org/10.1007/s10551-004-5263-6

Coleman, J. S. (1990). Foundations of Social Theory. Mass: Belknap Press of Harvard University Press, 300-321. 
Cronan, T. P., \& Al-Rafee, S. (2008). Factors that influence the intention to pirate software and media. Journal of Business Ethics, 78(4), 527-545. http://dx.doi.org/10.1007/s10551-007-9366-8

Drennan, J., Mort, G. S., \& Previte, J. (2006). Privacy, risk perception, and expert online behavior: An exploratory study of household end users. Journal of Organizational and End User Computing, 18(1), 1-22. http://dx.doi.org/10.4018/joeuc.2006010101

Eighmey, J. (1997). Profiling user responses to commercial web sites. Journal of Advertising Research, 37(3), 59-66.

Elena, F., \& Eva, M. (2007). Ecological consumer behaviour: an empirical analysis. International Journal of Consumer Studies, 31, 26-33.

Festinger, L. (1954). A theory of social comparison process. Human Relations, 7, 117-140. http://dx.doi.org/10.1177/001872675400700202

Fishbein, M., \& Ajzen, I. (1975). Belief, Attitude, Intention and Behavior: An Introduction to Theory and Research. Reading, MA: Addison-Wesley.

Frankena, W. K. (1970). The Concept of Morality. In G. Wallace \& Walker (Eds.), The Definition of Morality (pp. 146-173). London: Methuen.

Gaski, J. F., \& Nevin, J. R. (1985). The differential effects of exercised and unexercised power sources in a marketing channel. Journal of Marketing Research, 22, 130-142. http://dx.doi.org/10.2307/3151359

Goldblatt, D. L. (2005). Sustainable Energy Consumption and Society: Personal, Technological, or Social Change. Netherlands: Springer.

Hair, J. F. Jr., Black, W. C., Babin, B. J., Anderson, R. E., \& Tatham, R. L. (2006). Multivariate Data Analysis (6th ed.). NJ: Prentice Hall.

Hankins, M., French, D., \& Horne, R. (2000). Statistical guidelines for studies of the theory of reasoned action and the theory of planned behavior. Psychology \& Health, 15(2), 151-161. http://dx.doi.org/10.1080/08870440008400297

Hill, T., Smith, N. D., \& Mann, M. F. (1987). Role of efficacy expectations in predicting the decision to use advanced technologies: The case of computers. Journal of Applied Psychology, 72(2), 307-313. http://dx.doi.org/10.1037/0021-9010.72.2.307

Hoyer, W. D., \& MacInnis, D. J. (2003). Consumer Behavior. Boston: Houghton Mifflin.

Hsu, T. H., \& Lin, L. Z. (2006). Using fuzzy set theoretic techniques to analyze travel risk: An empirical study. Tourism Management, 27(5), 968-981. http://dx.doi.org/10.1016/j.tourman.2005.10.022

Jacoby, J., \& Kaplan, L. (1972). The components of perceived risk. In M. Venkatesan (Ed.), Proceedings of the $3^{\text {rd }}$ Annual Conference (pp. 382-393). Illinois: Association for Consumer Research, Champaign.

Joreskog, K. G., \& Sorbom, D. (1989). LISREL 7 Use's Reference Guide. Chicago: Scientific Software.

Kaiser, H. F. (1958). The varimax criterion for analysis rotation in factor analysis. Psychometrika, 23, 187-200. http://dx.doi.org/10.1007/BF02289233

Kates, R. W. (2000). Population and consumption: what we know, what we need know. Environment, 42(3), 10-19. http://dx.doi.org/10.1080/00139150009604872

Kerlinger, F. N. (1978). Foundation of Behavioral Research. NY: McGraw-Hill.

Kohlberg, L. (1984). The Psychology of Moral Development: Essays on Moral Development. NY: Harper \& Row.

Kotler, P. (2000). Marketing Management (10th ed.). NJ: Prentice-Hall.

Kotler, P., \& Armstrong, G. (2004). Principles of marketing (10th ed.). NJ: Prentice Hall.

Kujala, J. (2001). A multidimensional approach to finish managers' moral decision-making. Journal of Business Ethics, 34(3/4), 231-254. http://dx.doi.org/10.1023/A:1012583424721

Lovelock, C. H., \& Wirtz, J. (2007). Service Marketing. NJ: Prentice-Hall.

MacKenzie, S. B., Lutz, R. J., \& Belch, G. E. (1986). The role of attitude toward the advertising as a mediator of advertising effectiveness: A test of competing explanations. Journal of Marketing Research, 23(2), 130-143. http://dx.doi.org/10.2307/3151660 
McDougall, G. J. (1993). Older adults metamemory: coping, depression, and self-efficacy. Applied Nursing Research, 6(1), 28-30. http://dx.doi.org/10.1016/S0897-1897(05)80039-4

Mehrens, J., Cragg, P. B., \& Mills, A. M. (2001). A model of Internet adoption by SMEs. Information and Management, 39, 165-176. http://dx.doi.org/10.1016/S0378-7206(01)00086-6

Mostafa, M. M. (2007). Antecedents of egyptian consumers' green purchase intentions: A hierarchical multivariate regression model. Journal of International Consumer Marketing, 19(2), 97-126. http://dx.doi.org/10.1300/J046v19n02_06

Newhouse, N. (1990). Implication of attitude and behavior research for environmental conservation. Journal of Environmental Education, 22, 26-32. http://dx.doi.org/10.1080/00958964.1990.9943043

Norman, P., \& Conner, M. (2005). The theory of planned behavior and exercise: Evidence for the mediating and moderating roles of planning on intention-behavior relationships. Journal of Sport \& Exercise Psychology, 27(4), 488-504.

Nunnally, J. C. (1978). Psychometric Theory. NY: Mcgraw-Hill.

Ottman, J. (1993). Green Marketing: Challenges and Opportunities for The New Marketing. Lincolnwood, 1llinois: NTC Business Books.

Pavlou, P. A., \& Fygenson, M. (2006). Understanding and prediction electronic commerce adoption: An extension of the theory of planned behavior. MIS Quarterly, 30(1), 115-143.

Peattie, K. (1992). Green Marketing, Pitman Publishing, Marketing Management. London: Prentice-Hall.

Pedersen, P. E. (2005). Adoption of mobile internet services: An exploratory study of mobile commerce early adopters. Journal of Organizational Computing \& Electronic Commerce, 15(3), 203-222. http://dx.doi.org/10.1207/s15327744joce1503_2

Peter, J. P., \& Ryan, M. J. (1976). An investigation of perceived risk at the brand level. Journal of Marketing Research, 13(2), 184-188. http://dx.doi.org/10.2307/3150856

Reidenbach, R. E., \& Robin, D. P. (1990). Toward the development of a multidimensional scale for improving evaluations of business ethics. Journal of Business Ethics, 9(8), 639-653. http://dx.doi.org/10.1007/BF00383391

Rohm, A. J., \& Swaminathan, V. (2004). A typology of online shoppers based on shopping motivations. Journal of Business Research, 57(7), 748-757. http://dx.doi.org/10.1016/S0148-2963(02)00351-X

Roselius, T. (1971). Consumer rankings of risk reduction methods. Journal of Marketing, 35, 56-61. http://dx.doi.org/10.2307/1250565

Rotter, J. B. (1954). Social Learning and Clinical Psychology. Englewood Cliffs, NY: Prentice-Hall. http://dx.doi.org/10.1037/10788-000

Rotter, J. B. (1966). Generalized expectancies for internal versus external control of reinforcement. Psychological Monographs: General and Applied, 80(1), 1-28. http://dx.doi.org/10.1037/h0092976

Sarma, M., Septiani, S., Dewi, F. R., \& Siregar, E. H. (2013). The Impact of Entrepreneurial Marketing and Business Development on Business Sustainability: Small and Household Footwear Industries in Indonesia.false International Journal of Marketing Studies, 5(4), 110-122.

Schiffman, L.G., \& Kanuk, L. L. (2000). Consumer Behavior. Prentice Hall.

Schwartz, S. H., \& Tessler, R. C. (1972). A test of a model for reducing measured attitude-behavior discrepancies. Journal of Personality and Social Psychology, 24, 225-236. http://dx.doi.org/10.1037/h0033365

Sears, D. O., Peplau, L. A., \& Taylor, S. E. (1991). Social Psychology (7th ed.). Englewood Cliffs, NJ: Prentice-Hall.

Shaw, D., Shiu, E., \& Clarke, I. (2000). The contribution of ethical obligation and self-identity to the theory of planned behavior: An exploration of ethical consumers. Journal of Marketing Management, 16(8), 879-894. http://dx.doi.org/10.1362/026725700784683672

Stone, R. N., \& Gronhaug, K. (1993). Perceived risk: further considerations for the marketing Discipline. European Journal of Marketing, 27(3), 30-50. http://dx.doi.org/10.1108/03090569310026637

Tan, B. (2002). Understanding consumer ethical decision making with respect to purchase of pirated software. 
Journal of Consumer Marketing, 19(2), 96-111. http://dx.doi.org/10.1108/07363760210420531

Taylor, S., \& Todd, P. (1995). Decomposition and crossover effects in the theory of planned behavior: A study of consumer adoption intentions. International Journal of Research in Marketing, 12, 137-155. http://dx.doi.org/10.1108/07363760210420531

Teo, T. H., \& Pok, S. (2003). Adoption of WAP-enabled mobile phones among Internet users. The International Journal of Management Science, 31(6), 483.

Trevino, L. (1986). Ethical decision making in organizations: a person-situation interactionist model. Academy of Management Review, 11(3), 601-617.

Triands, H. C. (1989). The self and social behavior in differing cultural contexts. Psychological Review, 96(3), 506-520. http://dx.doi.org/10.1037/0033-295X.96.3.506

Venkatesh, V., \& Davis, F. D. (2000). A theoretical extension of the technology acceptance model: Four longitudinal field studies. Management Science, 46(2), 186. http://dx.doi.org/10.1287/mnsc.46.2.186.11926

Westaby, J. D. (2005). Behavioral reasoning theory: Identifying new linkages underlying intentions and behavior. Organizational Behavior and Human Decision Processes, 98, 97-120. http://dx.doi.org/10.1016/j.obhdp.2005.07.003

Wooten, D. B., \& Reed II., A. (2004). Playing it safe: susceptibility to normative influence and protective self-presentation. Journal of Consumer Research, 31(3), 551-556. http://dx.doi.org/10.1086/425089

\section{Copyrights}

Copyright for this article is retained by the author(s), with first publication rights granted to the journal.

This is an open-access article distributed under the terms and conditions of the Creative Commons Attribution license (http://creativecommons.org/licenses/by/3.0/). 